\title{
NATURE OF ANAEMIA IN RHEUMATOID ARTHRITIS \\ III. CHANGES IN THE BONE MARROW AND THEIR RELATION TO OTHER FEATURES OF THE DISEASE
}

\author{
BY \\ J. RICHMOND, D. L. GARDNER, L. M. H. ROY, AND J. J. R. DUTHIE \\ From the Rheumatic Unit, Northern General Hospital, Edinburgh
}

(RECEIVED FOR PUBLICATION MAY 10, 1956)

In a previous report (Roy, Alexander, and Duthie, 1955), the characteristics of the anaemia in rheumatoid arthritis were reviewed and it was shown that, although hypochromia of the red cell was a consistent feature, absorption of iron from the gut was unimpaired. On the other hand, the level of iron in the plasma was subnormal in the majority of cases and iron in the form of saccharated oxide, when administered by the intravenous route, was removed from the plasma of patients with rheumatoid arthritis more rapidly than from that of normal individuals. It had already been shown by Sinclair and Duthie $(1949,1950)$ and by others (Ross, 1950; Jeffrey, 1952, 1953a，1953b) that improvement in the anaemia followed the therapeutic use of intravenous iron in a proportion of cases of rheumatoid arthritis, although there was no relationship between the abnormality of iron metabolism, the degree of anaemia, and the response to treatment.

In these circumstances it was felt that a detailed study of the bone marrow with particular reference to the presence or absence of iron would be of considerable importance. The principal object of the investigation was to estimate the iron content of the marrow in a series of patients suffering from rheumatoid arthritis in order to determine whether the quantity of iron in the marrow was related to the degree of anaemia, the plasma iron level, the activity of the disease, or its duration. In addition, it was decided to study the cytology of the marrow in detail in order to define any characteristic or consistent changes in the cell pattern and to relate these changes to other features of the disease.

\section{Review of Literature}

Iron Content of Marrow.-In recent years it has been shown that iron may be demonstrated in marrow obtained at biopsy using an appropriate staining technique. Rath and Finch (1948) des- cribed the value of this procedure and claimed that the absence of stainable iron from the marrow indicated the need for the administration of iron. They examined 63 cases with a variety of diseases and found that anaemia due to deficiency of iron was associated with absence of stainable iron from the marrow. In anaemia due to infection and in pernicious anaemia, the iron content of the marrow tended to be high. Eleven of their cases were said to be normal and the marrows contained iron in small to moderate amounts. In their experience, only those cases in whom stainable iron was absent from the marrow responded to iron therapy. Masshof and Gruner (1951) found that the amount of iron which could be identified in the marrow by histochemical methods bore no relationship to the nature of the anaemia. Davidson and Jennison (1952) estimated the stainable iron content in 165 marrow samples from individual patients with a variety of diseases. The serum iron concentration was measured in 72 cases. Small to moderate amounts of iron were seen in the marrow from eleven patients without anaemia. They found that in iron deficiency anaemia there was no stainable iron in the marrow and the serum iron levels were low. In pernicious anaemia the iron content of the marrow was high and the serum iron level high. In the anaemia of sepsis and uraemia the amount of stainable iron in the marrow was high, but the level of serum iron low. The largest amounts of iron found in the marrow were in cases following repeated blood transfusion. Hutchison (1953), in a series of 141 cases, confirmed the findings of Rath and Finch (1948). He also claimed that, if iron was present in the marrow, the anaemia would not respond to iron administered orally or by the intravenous route. There were seventeen normal individuals in this group and iron was present in the marrow of all these subjects in amounts which could be easily recognized. Stevens, Coleman, and 
Finch (1953) agreed that stainable iron was absent from the marrow in anaemia due to iron deficiency and that there was a tendency for the iron content to be high in anaemia which was not associated with blood loss. In their series of 298 cases, there were 31 with normal blood findings. In four of these cases stainable iron was absent or present only in small amounts.

There are few accounts of the iron content of the bone marrow in rheumatoid disease. Smith (1953) estimated the iron in three cases of rheumatoid arthritis. Stainable iron was present in two cases and absent in the remaining case. She also studied the marrow of twenty normal individuals and failed to find stainable iron in four. Pratt and Johnson (1954) studied 116 patients suffering from a variety of diseases. There were five cases of rheumatoid arthritis in their series and they claimed that the iron content of the marrow was greater than normal in four.

Cytology of Marrow.-The cytology of the marrow in rheumatoid arthritis has been studied by several authors and the account given by Mester (1938) is among the earliest available. He described 33 cases of "primary chronic joint rheumatism" and claimed that an increase in plasma cells paralleled the activity of the disease. Kaether (1938) investigated 26 cases and regarded toxic granulation of the neutrophil polymorphs as characteristic of rheumatoid disease. Michelazzi (1937) reported a single case; he found proliferation of reticulo-endothelial and plasma cells. Marrow from 55 cases of "chronic poly- arthritis" was examined by Fleischhacker and Lachnit (1940). They stated that a significant $\Xi$ increase in reticulum cells and a slight plasmacytosis $\frac{O}{\omega}$ commonly occurred; only one case was described in detail and it was not stated how many of their cases $\overrightarrow{\bar{N}}$ were suffering from rheumatoid arthritis. Merlo 0 and Tortori-Donati (1945) described "histiolymphocytosis" in each of seven cases; in three the myeloid-erythroid ratio was less than 2:1. Luchesi, Luchesi, and Da Silva (1946) discussed 32 cases; they gave few details but claimed that plasmacytosis on was typical. Marmont (1948), in an exhaustive $\vec{\circ}$ review of 21 cases, found "active reticulo-endothelial $\vec{\overrightarrow{ }}$ systems", eosinophilia, plasmacytosis, and a ten- $\stackrel{\omega}{\mathscr{D}}$ dency to megaloblastosis. Nilsson (1948) described only the erythroid series; on the basis of the twelve? marrows examined, he claimed that a delay in the $\vec{v}$ maturation of red cells was common. Leitner (1949) gave details of two cases and concurred with the findings of Mester (1938). In a widely-quoted paper, Hayhoe and Smith (1951) described the marrow in ten cases of rheumatoid disease. They $\vec{c}$ found that the plasma cells exceeded 2 per cent. in nine cases, and in six where the plasma proteins had been estimated hyperglobulinaemia was $\frac{3}{0}$ recorded and associated with plasmacytosis in $\stackrel{\Phi}{-}$ each instance. Jasiński and Staehelin (1951\& $\overrightarrow{0}$ however, made a detailed study of 20 cases an Gु found plasmacytosis in only three instances. Fince; Crockett, Ross, and Bayles (1951) claimed that the was moderate depression of the red cell series but gave few details. Morelli and Arciello (1952) found a significant increase in the plasma cells in $\frac{\mathrm{Q}}{\mathbb{Q}}$

TABLE I

PRINCIPAL FINDINGS OF OTHER AUTHORS IN THE BONE MARROW OF RHEUMATOID ARTHRITIS

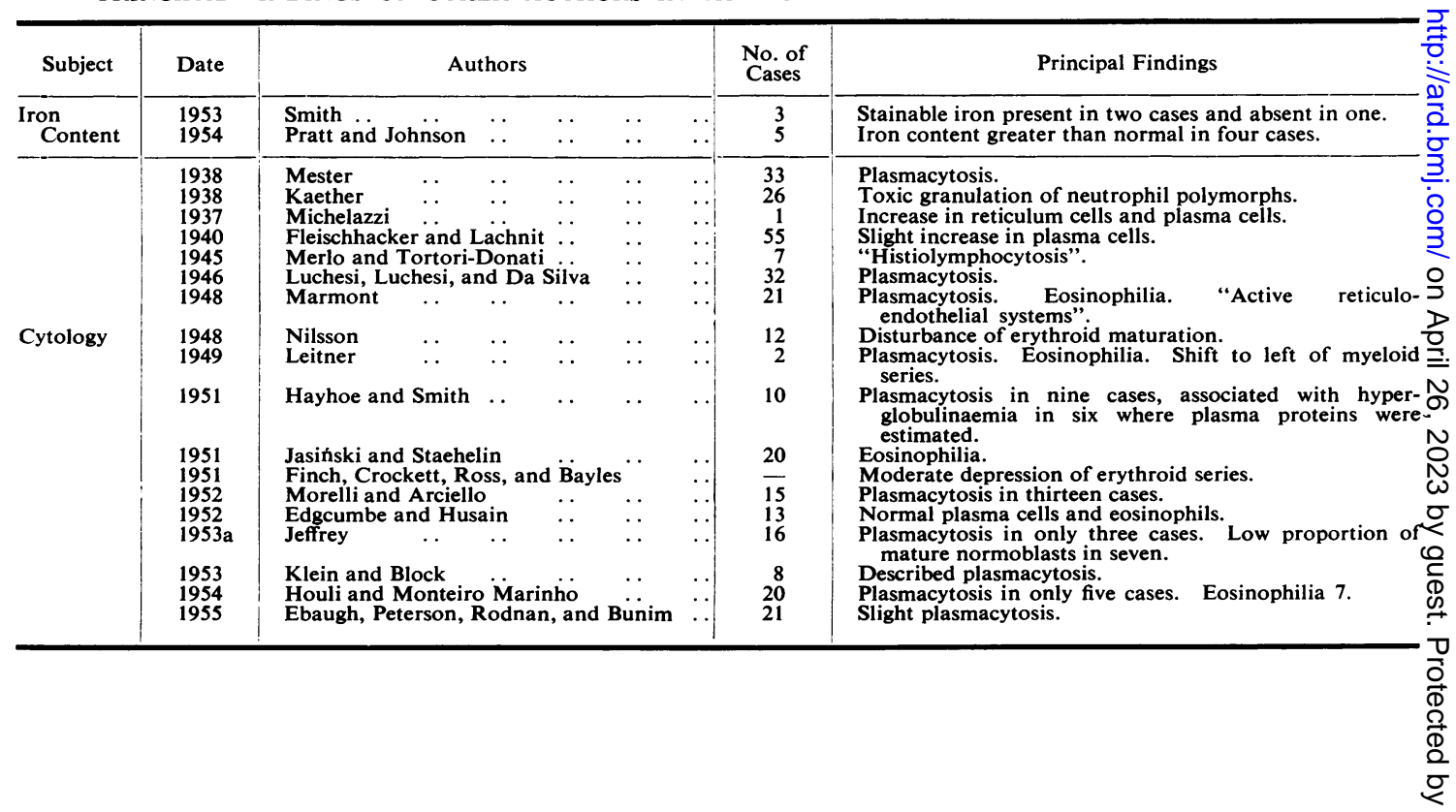


thirteen of their fifteen cases. Although the total protein level in the plasma was normal in all their cases, the albumin/globulin ratio was near unity. Edgcumbe and Husain (1952) investigated thirteen cases. The number of plasma cells was normal in every one and there was no evidence of eosinophilia. Differential cell counts were made on the marrow in sixteen cases of rheumatoid arthritis by Jeffrey (1953a). In only three instances did he find an increase of plasma cells; in seven cases the proportion of mature normoblasts was reduced. In describing a series of cases in which hyperglobulinaemia was associated with plasmacytosis, Klein and Block (1953) mention eight cases of rheumatoid arthritis. Houli and Monteiro Marinho (1954) examined the marrow in twenty cases: the plasma cell count was raised in five, but bore no relationship to the results of plasma flocculation tests; seven cases showed eosinophilia. Ebaugh, Peterson, Rodnan, and Bunim (1955) discussed 21 cases; they gave no figures but found that a slight plasmacytosis was a constant feature.

The principal findings of previous authors are summarized in Table I. It is obvious that there is a divergence of views in respect of many features and that the characteristics of the bone marrow in rheumatoid disease have not been established.

\section{Material}

Marrow samples were obtained from 64 in-patients in the Rheumatic Unit of the Northern General Hospital, Edinburgh. In each case a firm diagnosis of rheumatoid arthritis had been reached on clinical and radiological grounds. Care was taken to exclude patients with iron deficiency due to blood loss. Marrow biopsy was usually performed during the first 2 weeks of the patients' stay in hospital. During this period all were receiving the same basic regime of treatment consisting of bed rest, salicylates, and physiotherapy.

The composition of the group with regard to sex, age, duration, and activity of the disease is shown in Table II. In assessing the activity of the disease the number of joints involved, the degree of systemic disturbance, the haemoglobin level, and the erythrocyte sedimentation rate (E.S.R.) were considered. Patients were graded as very active, moderately active, or inactive.

The peripheral blood was examined within 3 days of marrow biopsy. The plasma iron concentration was measured in 58 cases and in 49 the plasma proteins were estimated.

\section{Methods}

Marrow Biopsy.-The technique used for obtaining the marrow sample was that described by Davidson (1941). In most cases the bone was penetrated with unusual ease and adequate samples were obtained at the first attempt. $2 \mathrm{ml}$. blood and marrow particles
TABLE II

\section{COMPOSITION OF GROUP}

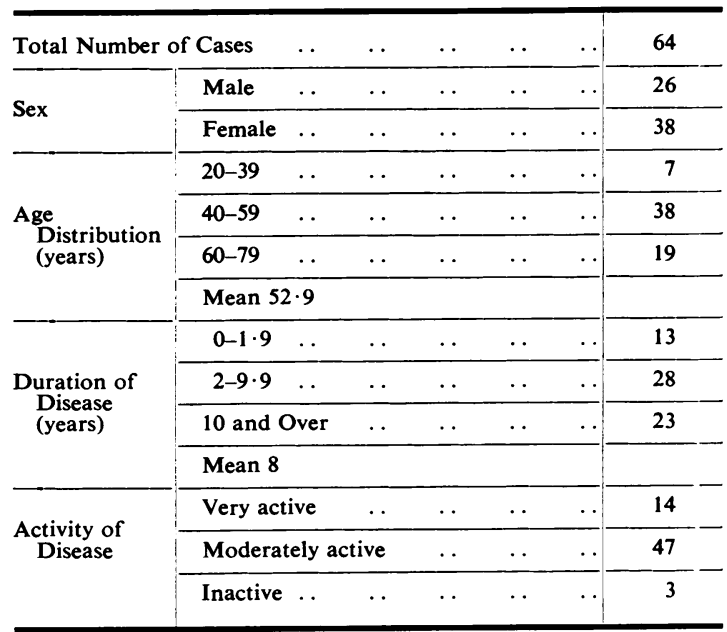

were aspirated by brisk suction. The greater part of the specimen was added to a tube containing heparin powder, and the remainder was divided between a tube containing Wintrobe's anti-coagulant and a clean, dry watch glass. The heparinized sample was submitted to histological and chemical examination. Nucleated cell counts were performed on the oxalated sample. Particles picked from the watch glass were used for preparing smears.

Histology.-Marrow particles taken from the tube containing heparin were placed in a small glass bottle in which was $20 \mathrm{ml}$. fixative (Hutchison, 1953). After 1 to 2 hrs the material was transferred to a thin glass test-tube, dehydrated in changes of alcohol, cleared in chloroform, and embedded in paraffin wax. The marrow fragments were found at the apex of the hemispherical block obtained by breaking the test-tube. Multiple sections cut from each block were stained by haematoxylin and eosin, by the Prussian blue method for ferric iron, and by the method of Barrett (1944).

Sections stained with haematoxylin and eosin provided an index of the adequacy of the sample. The distribution and nature of the cells in thirty of the marrows was assessed on the sections stained by Barrett's method. The ferric iron content of the marrow was estimated by the Prussian blue reaction. Staining was performed in glass jars previously rendered iron free; experiment showed that optimum results were obtained by immersing sections for $15 \mathrm{~min}$. at $56^{\circ} \mathrm{C}$. in a freshly prepared mixture of 4 per cent. hydrochloric acid and 4 per cent. potassium ferrocyanide.

The amount of stainable ferric iron present in the sections was assessed as nil, a trace, one plus, or two pluses. Control material was provided by marrow obtained from cases of iron deficiency anaemia, pernicious anaemia, haemochromatosis, and poly- 
cythaemia vera (Table III). In addition, marrow was aspirated at necropsy from five independent sites in each of two cases of rheumatoid disease. Estimates of the amount of iron in the individual aspirates in each instance gave good agreement.

Chemical Estimations of Non-Haem Iron in Bone Marrow.-A paper describing this method has been prepared for publication elsewhere and only a brief outline is given below:

All glassware and reagents were rendered iron-free.

The sample of marrow containing heparin as anticoagulant was used. Marrow particles were washed in 0.9 per cent. saline and transferred to an all-glass homogenizer containing $1 \mathrm{ml}$. distilled water. An even suspension of the tissue was made, the tube was rinsed with $0.5 \mathrm{ml}$. water, and the volume of the suspension was noted. A blank solution was prepared in the same way but omitting the marrow. All estimations were referred to this. Samples were taken for the estimation of iron and protein.

The iron was estimated by a method essentially that of Ramsay and Campbell (1954), using $1 \mathrm{ml}$. of the suspension and modifying the quantity of the other reagents to give a final volume of $3 \mathrm{ml}$. The protein was estimated in $0.2 \mathrm{ml}$. of the suspension, using the method of Lowry, Rosebrough, Farr, and Randall (1951), again modifying the quantity of the reagents to give a volume of $3 \mathrm{ml}$. All solutions were chilled and centrifuged in the cold to remove suspended material prior to colorimetric estimation.

The reproducibility of the method was tested by replicate estimations on a single sample. Six determinations were made giving a mean value of $0.45 \mu \mathrm{g}$. iron and a standard deviation of $\pm 0.077 \mu \mathrm{g}$. The mean value for protein was $786 \mu \mathrm{g} . \pm 54$.

The error in sampling was tested in two ways. One marrow sample was divided into four parts and each estimated separately. A mean value of $85 \mu \mathrm{g}$. iron $/ 100$ mg. protein was obtained with a range of $81-90 \mu \mathrm{g}$. At two separate necropsies three samples were obtained from the sternum and two from the iliac crest. A mean value of $45 \mu \mathrm{g} . / 100 \mathrm{mg}$. (range 31-53 $\mu \mathrm{g}$.) was obtained from the first case, and of $219 \mu \mathrm{g} . / 100 \mathrm{mg}$. (range 197-240 $\mu \mathrm{g}$.) from the second.
Myelogram.-Leishmann and Giemsa stains were used for staining marrow smears. In sixty cases the preparation was satisfactory and differential cell counts were made on 1,000 cells. Two observers (D.L.G. and J.R.) each counted 500 cells from a selection of two to four smears. The values given by Whitby and Britton (1953) for the normal myelogram were used for comparison. The differential cell counts in ten normal controls fell within these limits with one exception in which the plasma cell count reached $2 \cdot 1$ per cent. This figure was therefore taken as the upper limit of the normal range.

Peripheral Blood.-Blood was obtained by venepuncture and $3 \mathrm{ml}$. was mixed with Wintrobe's anticoagulant. In all cases the haemoglobin level, red cell count, E.S.R., and packed cell volume (P.C.V.) were estimated from this sample.

The haemoglobin level was measured colorimetrically by the alkaline haematin method of Clegg and King (1942) and compared with the artificial standard of Gibson and Harrison (1945).

Red cells were diluted with Hayem's solution in a standard red cell pipette and counted in a Neubauer chamber.

Westergren tubes were used for the estimation of the E.S.R. and the fall in $\mathrm{mm}$. was read at the end of one hour.

The P.C.V. was measured in a M.S.E. haematocrit centrifuge after $30 \mathrm{~min}$. at 3,000 r.p.m.

Plasma Iron.-The method used for measuring the plasma iron concentration was that described by Ro and others (1955).

Plasma Proteins.-These were estimated by the method of Gornall, Bardawill, and David (1949). The plasma protein levels of ten normal controls fell within the range given by these authors. The mean level of albumin was $4 \cdot 77 \mathrm{~g} . / 100 \mathrm{ml}$. (standard deviation $\pm 0 \cdot 38$ ), and of globulin $2 \cdot 26 \mathrm{~g} . / 100 \mathrm{ml}$. $( \pm 0 \cdot 16)$.

\section{Results}

Iron Content of Bone Marrow.-In 61 cases the iron content of the marrow was estimated by the

TABLE III

IRON CONTENT OF MARROW ESTIMATED BY PRUSSIAN BLUE REACTION IN TWELVE CASES WITH IRON DEFICIENCY OR EXCESS

\begin{tabular}{|c|c|c|c|c|c|c|c|c|c|c|c|}
\hline \multirow{2}{*}{\multicolumn{6}{|c|}{ Disease }} & \multirow{3}{*}{$\begin{array}{c}\begin{array}{c}\text { No. of } \\
\text { Cases }\end{array} \\
2\end{array}$} & \multicolumn{5}{|c|}{ Histochemical Assessment of Iron Content of Marrow } \\
\hline & & & & & & & \multirow{2}{*}{$\frac{\mathrm{Nil}}{2}$} & \multirow{2}{*}{$\frac{\text { Trace }}{-}$} & \multirow{2}{*}{+} & \multirow{2}{*}{$\frac{++}{-}$} & \multirow{2}{*}{$\frac{t+t}{-}$} \\
\hline Iron Deficiency Anaemia & $\cdots$ & $\cdots$ & . & $\cdots$ & $\cdots$ & & & & & & \\
\hline Pernicious Anaemia & $\cdots$ & $\cdots$ & . & $\cdots$ & $\cdots$ & 4 & - & - & - & 3 & 1 \\
\hline Polycythaemia Vera & . & . & . & . & $\cdots$ & 1 & - & - & - & 1 & - \\
\hline Haemochromatosis .. & $\cdots$ & $\ldots$ & . & . & $\cdots$ & 5 & - & - & - & 2 & 3 \\
\hline
\end{tabular}


Prussian blue reaction. In nineteen cases (31 per cent.) no stainable iron was found. In the other 42 cases (69 per cent.) iron was seen in varying amounts. The results are presented in Table IV. In six of the males ( 26 per cent.) and 13 of the females (34 per cent.) no stainable iron was seen.

TABLE IV

MARROW IRON ESTIMATED BY PRUSSIAN BLUE REACTION IN 61 CASES OF RHEUMATOID ARTHRITIS

\begin{tabular}{lll|c|c|c|c|c}
\hline Amount of Stainable Iron &.. & Nil & Trace & + & ++ \\
\hline Number of Cases &.. &.. & 19 & 11 & 26 & 5 \\
\hline
\end{tabular}

Marrow iron was estimated by the chemical method in 32 cases. In thirty of these the sample was divided and iron was estimated by the Prussian blue reaction and by the chemical method. The relationship between the results of the two methods is shown in Fig. 1. The mean of the chemical estimations in cases showing only a trace or no stainable iron is lower than the mean of those showing one or two pluses $(P=0 \cdot 05)$.

Peripheral Blood.-Examination revealed a moderate degree of anaemia in most cases. The mean level of haemoglobin for the whole group was 11.5 g. $/ 100 \mathrm{ml}$. (78 per cent.). In 57 cases the red cells were normocytic and hypochromic. In three females microcytosis was present. In only five cases were the red cells normochromic. The average mean corpuscular volume (M.C.V.) for the whole group was 83.3 c. $\mu$. and average mean corpuscular haemoglobin concentration (M.C.H.C.) $28 \cdot 7$ per cent.

The E.S.R. ranged from 3 to $108 \mathrm{~mm}$./ $\mathrm{hr}$ (mean $47 \mathrm{~mm} . / \mathrm{hr}$ ).

The plasma iron concentration ranged from 24 to $146 \mu \mathrm{g} . / 100 \mathrm{ml}$.

In the female patients anaemia was more severe and the disease more active than in the male patients. The mean values for haemoglobin, red cell count,

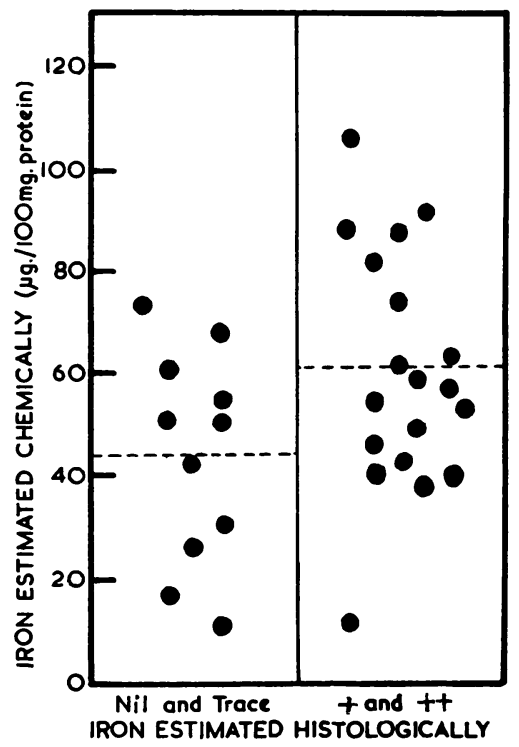

Fig. 1.-Comparison of iron estimations by chemical and histological methods.

mean corpuscular volume, mean corpuscular haemoglobin concentration, erythrocyte sedimentation rate, and plasma iron concentration for the two sexes are summarized in Table $\mathrm{V}$.

Relationship between Amount of Iron in Marrow and Other Features of the Disease.-No relationship was found between the amount of iron in the marrow estimated histologically or chemically, and the haemoglobin level, red cell count, M.C.H.C., E.S.R., or plasma iron concentration. The results of this analysis are shown in Table VI (overleaf).

There was a tendency for stainable iron to be absent from the marrow more frequently as the duration of the disease increased. In the group of short duration (0-1.9 yrs), 18 per cent. had no iron in the marrow compared with 41 per cent. in the group where the duration of disease was 10 years

TABLE $\mathrm{V}$

FINDINGS IN PERIPHERAL BLOOD OF 26 MALE AND 38 FEMALE CASES OF RHEUMATOID ARTHRITIS

\begin{tabular}{|c|c|c|c|c|c|c|c|}
\hline \multirow[b]{2}{*}{ Sex } & \multirow[b]{2}{*}{$\begin{array}{l}\text { No. of } \\
\text { Cases }\end{array}$} & \multicolumn{6}{|c|}{ Peripheral Blood Values (Mean and Standard Deviation) } \\
\hline & & Hb. (g./100 ml.) & $\begin{array}{c}\text { Red Cell Count } \\
\text { (millions/c.mm.) }\end{array}$ & $\begin{array}{l}\text { Mean } \\
\text { Corpuscular } \\
\text { Volume } \\
\text { (cu.p) }\end{array}$ & $\begin{array}{c}\text { Mean } \\
\text { Corpuscular } \\
\text { Hb Concentration } \\
\text { (g. per cent.) }\end{array}$ & $\begin{array}{c}\text { Erythrocyte } \\
\text { Sedimentation } \\
\text { Rate } \\
\text { (mm./hr.) }\end{array}$ & $\begin{array}{c}\text { Plasma Iron } \\
(\mu \mathrm{g} . / 100 \mathrm{ml} .)\end{array}$ \\
\hline Males .. & 26 & $\begin{array}{c}12 \cdot 4 \pm 1 \cdot 2 \\
(84 \text { per cent. })\end{array}$ & $4 \cdot 94 \pm 0 \cdot 37$ & $84 \cdot 6 \pm 2 \cdot 4$ & $29 \cdot 1 \pm 3 \cdot 9$ & $39 \pm 8$ & $\begin{array}{c}92 \pm 11 \\
(23 \text { cases })\end{array}$ \\
\hline Females & 38 & $\begin{array}{c}10.9 \pm 0.9 \\
(73 \text { per cent.) }\end{array}$ & $4 \cdot 94 \pm 0 \cdot 56$ & $82 \cdot 4 \pm 3 \cdot 6$ & $28 \cdot 7 \pm 4 \cdot 9$ & $52 \pm 7$ & $\begin{array}{c}80 \pm 29 \\
(35 \text { cases })\end{array}$ \\
\hline
\end{tabular}


RELATIONSHIP BETWEEN PERIPHERAL BLOOD VALUES AND IRON CONTENT OF MARROW*

\begin{tabular}{|c|c|c|c|c|c|c|c|c|}
\hline Group & $\begin{array}{l}\text { Stainable } \\
\text { Iron }\end{array}$ & $\begin{array}{c}\text { No. } \\
\text { of } \\
\text { Cases }\end{array}$ & $\begin{array}{l}\text { Non-Haem Iron } \\
\text { ( } \mu \text { g./100 mg. } \\
\text { protein) }\end{array}$ & $\begin{array}{l}\text { Plasma Iron } \\
(\mu \mathrm{g} . / 100 \mathrm{ml} .)\end{array}$ & $\begin{array}{l}\mathrm{Hb} \text {. } \\
(\mathrm{g} . / 100 \mathrm{ml} .)\end{array}$ & $\begin{array}{c}\text { Red Cell } \\
\text { Counts } \\
\text { (mill./c.mm.) }\end{array}$ & $\begin{array}{c}\text { Erythrocyte } \\
\text { Sedimentation } \\
\text { Rate } \\
(\mathrm{mm} . / \mathrm{hr} .)\end{array}$ & $\begin{array}{l}\text { Mean } \\
\text { Corpuscular } \\
\text { Haemoglobin } \\
\text { Concentration } \\
\text { (g. per cent.) }\end{array}$ \\
\hline \multirow{2}{*}{1} & \multirow{2}{*}{$+\div$} & 5 & - & 89 & $11 \cdot 2$ & $4 \cdot 33$ & 66 & $32 \cdot 0$ \\
\hline & & 5 & 66 & 89 & $11 \cdot 2$ & $4 \cdot 33$ & 66 & $32 \cdot 0$ \\
\hline \multirow{2}{*}{ II } & \multirow{2}{*}{ it } & 26 & - & 89 & $11 \cdot 7$ & $4 \cdot 77$ & 46 & $29 \cdot 4$ \\
\hline & & 15 & 58 & 84 & $11 \cdot 7$ & $4 \cdot 85$ & 42 & $28 \cdot 4$ \\
\hline \multirow{2}{*}{\multicolumn{2}{|c|}{$\begin{array}{l}\text { Mean Values for } \\
\text { Cases in Groups } \\
\text { I and II }\end{array}$}} & 31 & - & 89 & $11 \cdot 6$ & $4 \cdot 70$ & 49 & $29 \cdot 8$ \\
\hline & & 20 & 61 & 85 & $11 \cdot 6$ & $4 \cdot 72$ & 48 & $29 \cdot 3$ \\
\hline \multirow{2}{*}{ III } & \multirow{2}{*}{ Trace } & 11 & - & 93 & $11 \cdot 7$ & $4 \cdot 83$ & 40 & $28 \cdot 7$ \\
\hline & & 4 & 42 & 88 & $11 \cdot 7$ & $4 \cdot 80$ & 36 & $28 \cdot 9$ \\
\hline \multirow{2}{*}{ IV } & \multirow{2}{*}{ Nil } & 19 & - & 77 & $11 \cdot 2$ & $\overline{4 \cdot 69}$ & 47 & $28 \cdot 9$ \\
\hline & & 7 & 47 & 73 & $11 \cdot 7$ & $4 \cdot 74$ & 35 & $29 \cdot 8$ \\
\hline \multirow{2}{*}{\multicolumn{2}{|c|}{$\begin{array}{l}\text { Mean Values for } \\
\text { Cases in Groups } \\
\text { III and IV }\end{array}$}} & 30 & - & 83 & $11 \cdot 4$ & $4 \cdot 74$ & 44 & $28 \cdot 9$ \\
\hline & & 11 & 45 & 78 & $11 \cdot 7$ & $4 \cdot 76$ & 35 & $29 \cdot 5$ \\
\hline
\end{tabular}

* In each group the mean values for all cases are given by the upper line of figures; the lower line gives the values for cases in which both histological and chemical estimates of iron were made.

or longer. 29 per cent. of the intermediate group showed no stainable iron.

It was also found that, although the plasma iron concentration was subnormal, the level could not be clearly related to any other feature of the disease.

When the haemoglobin level was related to the E.S.R. there was a highly significant correlation between the degree of anaemia and the activity of the disease $(r=0.474 ;$ S.E. of $r=0.126 ; P<0.01)$. In 35 cases the peripheral blood had been examined on three occasions during the four weeks before marrow biopsy. When the average haemoglobin and average E.S.R. for these cases were compared the correlation was confirmed.

Cytology of Marrow.-The architecture of the marrow was normal. There was no histological evidence of hyperplasia of the reticulo-endothelial system.

Examination of the marrow smears confirmed that the samples were of normal cellularity.

Myeloid Series.-The total neutrophil count (neutrophil precursors and neutrophil polymorphs) ranged from $43 \cdot 2$ to $74 \cdot 1$ per cent. (normal range 22-73 per cent.). In one case only was the upper normal limit exceeded. There was no evidence of any disturbance of white cell formation or maturation.
The total eosinophil count (eosinophil precursors and eosinophil polymorphs) was above the uppe? limit of normal $(7 \cdot 5$ per cent.) in five cases $(8 \cdot 5$ peto cent.). In these five cases the counts ranged from $8 \cdot 1$ to $12 \cdot 7$ per cent.

Erythroid Series.-The total normoblast count (early, intermediate, and late) ranged from $10 \cdot 0$ to 46.8 per cent. (normal range 11 to 34 per cent.). In sixteen cases ( 27 per cent.) the proportion of normoblasts exceeded 34 per cent., but in only five did the count exceed 40 per cent. In these sixteen cases the myeloid/erythroid ratio was less than 2:1.

In two cases macronormoblasts were seen. Neither case had macrocytosis or evidence of folic acid or vitamin $B_{12}$ deficiency. In the whole group no other abnormality of maturation was observed, nor was any disturbance of haemoglobinization recognized. Examination of the total normoblast count in those cases which had received gold (32 cases) or phenylbutazone (eleven cases) revealed no evidence that previous treatment with these drugs had influenced normoblast development.

Plasma Cells.-The plasma cell count ranged from 0 to 5 per cent. (normal range 0 to $2 \cdot 1$ per cent.) and in 21 cases ( 35 per cent.) the number of plasma cells exceeded $2 \cdot 1$ per cent.

In the 49 cases where the plasma proteins were 
estimated, the mean albumin level was 3.73 g. $/ 100 \mathrm{ml}$. (standard deviation \pm 0.49 ) and the mean globulin level $2.43 \mathrm{~g} . / 100 \mathrm{ml}$. $( \pm 0 \cdot 43)$.

Relationship of Cytology of Marrow to Other Features of the Disease.- Normoblastosis or eosinophilia or plasmacytosis was not related to the degree of anaemia, the activity of the disease, the plasma iron level, or the iron content of the marrow.

Although the total normoblast count for most cases was within the normal range, it was found that the haemoglobin level tended to be low when the normoblast count was low. This association was clearer when the cases of short duration (0 to 1.9 years) were excluded. For the 48 cases in the groups of intermediate and long duration there was a highly significant correlation between the haemoglobin level and the total normoblast count $(r=0.467$; S.E. of $r=0$ is $0.144 ; P<0.01)$.

For the 45 cases where both values were available, there was a highly significant correlation between the plasma cell count in the marrow and the globulin level in the plasma $(r=0.479$; S.E. of $r=0$ is 0.150 ; $P<0.01$ ) (Fig. 2).

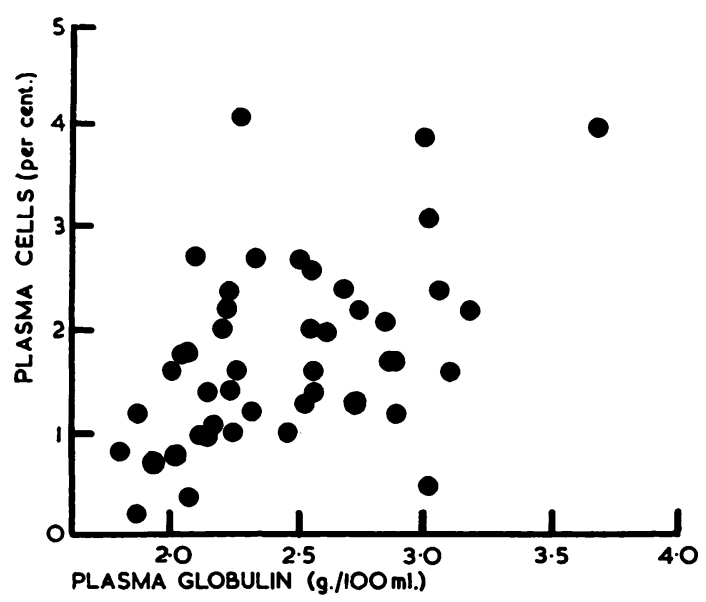

Fig. 2.-Relationship between plasma cell count in marrow and plasma globulin level.

The number of plasma cells was not related to the degree of anaemia or to the activity of the disease. There was, however, a definite tendency for the plasma cell count to fall as the duration of the disease increased. The mean plasma cell count for the early group (0-1.9 yrs) was 2.6 per cent., for the intermediate group (2-9 yrs) 1.72 per cent., and for the group of long duration (10 yrs and over) 1.34 per cent. The association between the plasma cells and the duration of the disease is shown in Table VII.

TABLE VII

EFFECT OF DURATION OF DISEASE ON PLASMA CELL COUNT IN BONE MARROW IN SIXTY CASES OF RHEUMATOID ARTHRITIS

\begin{tabular}{|c|c|c|c|c|}
\hline Duration of Disease (year & & $0-1 \cdot 9$ & $2-9 \cdot 9$ & $\begin{array}{l}10 \text { and } \\
\text { Over }\end{array}$ \\
\hline \multicolumn{2}{|c|}{ Mean Plasma Cell Count (per cent.) } & $2 \cdot 6$ & $1 \cdot 7$ & $1 \cdot 3$ \\
\hline Standard Error of Mean & . & 0.344 & $0 \cdot 172$ & $0 \cdot 193$ \\
\hline Number of Cases & . & 12 & 26 & 22 \\
\hline
\end{tabular}

\section{Discussion}

A review of the literature provides little information as to the iron content of the marrow in rheumatoid arthritis. In anaemia arising from iron deficiency it is generally accepted that iron in the form demonstrated by the Prussian blue staining reaction is absent from the marrow, and it has been stated (Hutchison, 1953) that the administration of iron is of benefit only in these conditions. Certain features, such as persistent hypochromia of the red cell and low plasma iron values, have suggested that a deficiency of iron may play a part in the production of the anaemia of rheumatoid arthritis. This view receives some support from the reports of improvement in the anaemia following the administration of large doses of iron by the intravenous route. In anaemia due to other causes, such as infection, malignant disease, and uraemia, however, the amount of iron in the marrow tends to be greater than normal while the level in the plasma is frequently below normal. Since there is no evidence that absorption of iron from the gut is impaired in rheumatoid arthritis, or that it is excreted in abnormal amounts, there seems no reason to suppose that stores of iron in the body would be inadequate.

An attempt has therefore been made in the present investigation to determine the iron content of the marrow in a large group of patients.

Marrow iron was estimated in 61 cases by the Prussian blue reaction. In nineteen cases $(31$ per cent.) no stainable iron could be demonstrated microscopically. Of these, six were male and thirteen female. In a further eleven cases only traces of iron were present. Marrow iron was also estimated by the chemical method in thirty cases and, although measurable amounts were found in all, a rough correlation existed between the results of the two methods. It must be borne in mind that, whereas the staining reaction only reveals iron in the form of haemosiderin, the chemical method measures all the non-haem iron in the sample. 
No correlation could be demonstrated between the presence or absence of stainable iron in the marrow or the amount estimated chemically and the haemoglobin level, erythrocyte count, mean corpuscular haemoglobin concentration, erythrocyte sedimentation rate, or plasma iron concentration. This lack of correlation suggests that deficiency of iron in the marrow is not an important factor in the causation of anaemia in rheumatoid arthritis. On the other hand, there was a highly significant correlation between the E.S.R. and haemoglobin level. Protein and porphyrin metabolism may be profoundly altered in rheumatoid arthritis (Jeffrey, 1953b). Hypochromia of the red cells could therefore arise from factors other than inadequate supplies of iron. The improvement in the anaemia which follows the administration of cortisone or corticotrophin without additional iron therapy would favour this idea.

The cytological pattern of the bone marrow was examined in sixty cases and did not differ significantly from normal. No evidence has been obtained to support the views of those authors who have described various abnormalities as characteristic of the marrow in this disease.

In 35 per cent. of cases there was a slight increase in the proportion of plasma cells. Plasmacytosis of similar degree occurs in many diseases and is commonly associated with conditions where the production of antibodies is increased (Marshall, 1956). A highly significant correlation was found in this series of cases between the marrow plasma cell count and the level of globulin in the plasma, but there is not as yet any evidence of increased production of antibodies in rheumatoid arthritis. In contrast to the finding of Hayhoe and Smith (1951) hyperglobulinaemia was not constantly associated with plasmacytosis.

No abnormal changes in the myeloid cell series were found. The five patients in whom eosinophilia was demonstrated differed in no other way from the remainder of the group. It is of interest that eosinophilia in the bone marrow in rheumatoid arthritis has been reported most frequently from countries where parasitic disease is endemic.

Alexander, Richmond, Roy, and Duthie (1956) state that an unusually rapid rate of destruction of circulating red cells may be a factor in the production of anaemia in rheumatoid arthritis. In a study of the erythroid cell series in the marrow, it was found that there was a slight increase in the proportion of normoblasts in 27 per cent. of cases, while in the remainder the normoblast count was within the normal range. In contrast to the findings when anaemia is due to increased blood destruction, there was a direct relationship between the haemoglobin level and the normoblast count, suggesting an inadequate normoblast response in the anaemia of this disease. This association became highly significant when cases of less than 2 years duration were excluded. It would appear from this that inadequate formation of normoblasts is more pronounced in the later stages of the disease. Disturbance of the maturation of erythroid precursors has been described by Nilsson (1948) and Jeffrey (1953a), but such changes were not observed in the present series, nor was frank hypoplasia found in any case.

It becomes apparent that anaemia in rheumatoid arthritis is likely to arise from more than one cause. It bears a significant relationship to the activity of the disease. It is associated with, but not directly due to, a disturbance of iron metabolism. While iv the iron content of the marrow was low in half of the cases which have been studied, iron was present in the remainder in easily measurable amounts. Persistent hypochromia of erythrocytes is evidence $\vec{c}$ of a disturbance in haemoglobin synthesis. An increased rate of red cell destruction may contribute to the anaemia, and it appears that the normoblast response is inadequate, particularly in the later $\mathbb{Q}$ stages of the disease. The role of iron is difficul $\vec{\theta}$ to evaluate. The iron content of the marrow w of frequently low, but it could not be related to the peripheral blood findings and therefore did not appear to be an important factor in the production of anaemia. Improvement in the anaemia has been shown to follow the use of iron intravenously, but its mode of action is not yet clear.

\section{Summary}

(1) The iron content and cytology of the sternal marrow has been examined in 64 cases of rheumatoid arthritis.

(2) In 31 per cent. of cases no iron could be demonstrated by the Prussian blue method.

(3) Marrow iron was estimated by a chemical method in 32 instances. Iron in measurable amounts was present in all the specimens examined.

(4) No relationship was demonstrable between the amount of iron in the marrow, estimated by the two methods, and the haemoglobin level, erythrocyte count, mean corpuscular haemoglobin con- $\sigma$ centration, erythrocyte sedimentation rate, or plasma iron level.

(5) There was a highly significant correlation between the haemoglobin level and the erythrocyte sedimentation level.

(6) Examination of the cytology of the marrow revealed no significant abnormality. In 35 per 0 
cent. of cases there was a slight increase in the proportion of plasma cells. When all the cases in the series were considered, there was a significant relationship between the proportion of plasma cells and the level of globulin in the serum.

(7) The proportion of normoblasts was directly related to the haemoglobin level, especially in cases of more than 2 years' duration, suggesting a failure of the marrow to respond to the anaemia.

(8) It would appear that, although the degree of anaemia in rheumatoid arthritis is related to the activity of the disease, it does not arise directly from a deficiency of iron in the marrow. Other factors, such as increased destruction of red cells, depression of the formation of red cell precursors, and impaired synthesis of haemoglobin, may be important.

We wish to express our thanks to Dr. P. E. Brown, of the Department of Public Health and Social Medicine, Edinburgh University, and to Dr. J. L. Potter, Nuffield Research Fellow, for statistical help, and to Miss Dorothy Anderson, haematological technician, for her accurate work throughout this investigation.

Throughout the period when this work was done, the Rheumatic Unit was in receipt of grants from the Nuffield Foundation, the Medical Research Council, and Boots Pure Drug Company.

\section{REFERENCES}

Alexander, W. R. M., Richmond, J., Roy, L. M. H., and Duthie, J. J. R. (1956). Annals of the Rheumatic Diseases, 15, 12.

Barrett, A. M. (1944). J. Path. Bact., 56, 133.

Clegg, J. W., and King, E. J. (1942). Brit. med. J., 2, 329.

Davidson, L. S. P. (1941). Edinb. med. J., 48, 678.

Davidson, W. M., and Jennison, R. F. (1952). J. clin. Path., 5, 281.

Ebaugh, F. G., Peterson, R. E., Rodnan, G. P., and Bunim, J. J. (1955). Med. clin. N. Amer., 39, 489.

Edgcumbe, J. O. P., and Husain, O. A. N. (1952). Annals of the Rheumatic Diseases, 11, 257.

Finch, S. C., Crockett, C. L., Ross, J. F., and Bayles, T. B. (1951). Blood, 6, 1034.

Fleischhacker, H., and Lachnit, V. (1940). Wien. klin. Wschr., 53, 189.

Gibson, Q. H., and Harrison, D. C. (1945). Biochem. J., 39, 490.

Gornall, A. G., Bardawill, C. J., and David, M. M. (1949). J. biol. Chem., 177, 751 .

Hayhoe, F. G. J., and Smith, D. Robertson (1951). J. clin. Path., 4, 47.

Houli, J., and Monteiro Marinho, H. (1954). Annals of the Rheumatic Diseases, 13, 327.

Hutchison, H. E. (1953). Blood, 8, 236.

Jasiński, B., and Staehelin, A. (1951). Schweiz. med. Wschr., 81, 619.

Jeffrey, M. R. (1952). Annals of the Rheumatic Diseases, 11, 162.

- (1953a). Blood, 8, 502 .

(1953b). Brit. med. J., 2, 912

Kaether, H. (1938). Z. Rheumaforsch., 1, 473.

Klein, H., and Block, M. (1953). Blood, 8, 1034.

Leitner, S. J. (1949). "Bone Marrow Biopsy", Engl. trans. by C. W. C. Britton and E. Neumark. Churchill, London.

Lowry, O. H., Rosebrough, N. J., Farr, A. L., and Randall, R. J. (1951). J. biol. Chem., 193, 265.

Luchesi, M., Luchesi, O., and Da Silva, M. P. (1946). Rev. argent. Reum., 10, 294.

Marmont, A. (1948). Arch. “Maragliano" Patol. Clin., 3, 1289.

Marshall, A. H. E. (1956). "An Outline of the Cytology and Pathology of the Reticular Tissue". Oliver and Boyd, Edinburgh.

Masshoff, W., and Gruner, P. (1951). Acta haemat. (Basel), 5, 19.

Merlo, P., and Tortori-Donati, B. (1945). Rass. Fisiopat. clin. ter., 17,' Suppl. 2, p. 37.

Mester, A. (1938). Z. Rheumaforsch., 1, 535.

Michelazzi, A. M. (1937). Minerva med. (Torino), 28, (2) 609. (Quoted in J. Amer. med. Ass. (1938), 110, 404.)

Morelli, A., and Arciello, G. (1952). Riform. med., 66, 620.
Nilsson, F. (1948). Acta med. scand., Suppl. 210.

Pratt, P. T., and Johnson, M. E. (1954). Arch. intern. Med., 93, 725. Ramsay, W. N. M., and Campbell, E. A. (1954). Biochem. J., 58, 313.

Rath, C. E., and Finch, C. A. (1948). J. Lab. clin. Med., 33, 81.
Ross, D. N. (1950). Annals of the Rheumatic Diseases, 9, 358.

Roy, L. M. H., Alexander, W. R. M., and Duthie, J. J. R. (1955). Ibid., 14, 63.

Sinclair, R. J. G., and Duthie, J. J. R. (1949). Lancet, 2, 646.

Sinclair, R. J. G., and Duthie, J., J. R.

Smith, M. D. (1953). Glasg. med. J., 34, 41.

Stevens, A. R., Jr., Coleman, D. H., and Finch, C. A. (1953). Ann. intern. Med., 38, 199.

Whitby, L. E. H., and Britton, C. J. C. (1953). "Disorders of the Blood", 7th ed. Churchill, London.

Nature de l'anémie dans l'arthrite rhumatismale.

III. Altérations de la moelle osseuse et leurs

relations avec les autres caractères de la maladie

\section{RÉSUMÉ}

(1) La teneur en fer et la cytologie de la moelle sternale furent examinées dans 64 cas d'arthrite rhumatismale.

(2) Dans 31 pour cent des cas on ne décela pas de fer par la méthode du bleu de Prusse.

(3) Le fer dans la moelle fut dosé par une méthode chimique dans 32 cas. Du fer en quantités mesurables fut trouvé dans tous les prélèvements.

(4) Aucun rapport ne fut démontrable entre la quantité de fer dans la moelle, déterminée par les deux méthodes, et le taux d'hémoglobine, la numération érythrocytaire, la valeur globulaire, la vitesse de sédimentation érythrocytaire ou le taux de fer plasmatique.

(5) Il y avait une corrélation très significative entre le taux d'hémoglobine et la vitesse de sédimentation globulaire.

(6) L'examen cytologique de la moelle ne révéla aucune anomalie significative. Dans 35 pour cent des cas il $y$ eut une légère augmentation du nombre des cellules plasmatiques. Quand tous les cas de la série furent considérés, on constata une relation significative entre le nombre des cellules du plasma et le taux d'hémoglobine sérique.

(7) La proportion des normoblastes était directment liée au taux d'hémoglobine, en particulier dans les cas remontant à plus de deux ans, ce qui suggère une défection de la moelle devant l'anémie.

(8) Il semblerait que, bien que le degré d'anémie dans l'arthrite rhumatismale soit lié à l'activité de la maladie, il ne découle pas directement d'une carence de fer dans la moelle. D'autres facteurs, tels que destruction accrue des hématies, entrave à la formation des précurseurs des hématies et synthèse diminuée de l'hémoglobine, peuvent être importants.

\section{La naturaleza de la anemia en la artritis reumatoide \\ III. Alteraciones de la médula ósea y sus relaciones con otros caracteres de la enfermedad}

\section{SUMARIO}

(1) Se investigaron el contenido de hierro y la citología de la médula esternal en 64 casos de artritis reumatoide.

(2) En el $31 \%$ de los casos no se pudo demostrar presencia de hierro por el método de azúl de Prusia.

(3) Se procedió al dosaje de hierro en la médula por un método químico en 32 casos, encontrándole en cantidades mensurables en todos los espécimenes.

(4) No se evidenció relación alguna entre la cantidad de hierro en la médula, determinada por ambos métodos, y las cifras de hemoglobina, de los ertrocitos, la concentración corpuscular media de hemoglobina, la 
velocidad de sedimentación eritrocitaria y la cifra de hierro plasmático.

(5) Se encontró correlación muy significativa entre las cifras de hemoglobina y la velocidad de sedimentación globular.

(6) La investigación citológica de la médula no evidenció anomalías significativas. En un $35 \%$ de los casos hubo una pequeña aumentación de la cifra de células plasmáticas. Al considerar todos los casos de la serie, se halló una relación significativa entre las cifras de las células del plasma y las de hemoglobina sérica.
(7) Hubo relación directa entre la proporción de normoblastos y las cifras de hemoglobina, en particular en los casos de más de dos años de duración, lo que sugiere la falla de la médula en responder a la anemia.

(8) Parece pues que, aunque el grado de anemia en la artritis reumatoide esté ligado a la actividad mórbida, éste no procede directamente de una carencia de hierro en la médula. Otros factores, tales como destrucción más rápida de eritrocitos, impedimento en la formación de sus precursores y síntesis disminuida de hemoglobina pueden tener importancia. 